DOI https://doi.org/10.30525/978-9934-26-004-9-82

\title{
ЛІНІЙНИЙ ПАРК - ФЕНОМЕН ПОСТІНДУСТРІАЛЬНОГО ЧАСУ
}

\author{
Гамалія К. М. \\ доктор мистеитвознавства, професор, \\ доиент кафедри теорії та історії мистеитва \\ Національної академії образотворчого мистецтва та архітектури \\ м. Київ, Украӥна
}

Сад, цю, можливо, найвищу й найскладнішу форму мистецтва, можна розуміти як серію запланованих і втілених у життя взаємозв'язків людини зі створеними нею спорудженнями та природним оточенням [1]. Впродовж свого існування від прадавнини до сьогодення цей витвір людського вміння та художньої уяви постійно трансформувався, утворюючи нові різновиди. Дослідженню еволюції саду в часі й просторі присвятив свої праці англійський ландшафтний архітектор Том Тернер, за теорією якого виділяється три основні мотивації, що обумовили створення різних типів саду: для тіла (палацовий, домашній, публічний, міський), для активності (мисливський, ботанічний, зоологічний) та для душі (храмовий, монастирський, церемоніальний) [2, с. 11].

На порозі III тисячоліття склався і навіть вийшов на передній план ще один тип мотивації - «Для екології», необхідний для задоволення нагальних вимог екологічного імперативу. Наслідком розвитку техногенної цивілізації стала поява постіндустріальних ландшафтів, відзначених нагромадженням промислових відходів, які не підлягають утилізації, та накопиченням будівель, що руйнуються, залишені за непотрібністю. Синтетична природа садово-паркового мистецтва [3] надала можливість ландшафтним архітекторам створити на руїнах минувшої економічної функціональності яскраві зразки парків, що задовольняють сучасні естетичні вимоги. Викликам часу відповідає так званий «лінійний парк» - парк у міській чи приміській зоні, який має довгу, витягнуту форму і представлений кількома різновидами.

\section{Парки на старих залізничних коліях}

Реконструкція Парижу проходила у перші гарячкові роки століття залізниць. Париж між 1851 та 1870 рр. став типовою столицею промислового віку. У жодному місті того часу зміни, викликані розвитком промисловості, не відбилися $з$ такою силою. Коли ж мова 
заходить про садово-паркове мистецтво Франції, перш за все спадає на думку чудовий витвір Ленотра, резиденція французьких королів Версаль, регулярний парк епохи бароко. Проте зелене будівництво в цій країні і надалі активно розвивалося, і в 1993 р. саме в Парижі був закладений перший у світі парк на залізничній колії - Promenad plante (Прогулянка серед рослин). Розташований цей парк повздовж старої залізничної колії, якою в середині XIX століття до міста завозили кам'яне вугілля [4]. Унікальність його концепції полягає у чергуванні відкритих та закритих просторів, висячих садів і тунелів. Цікаво відзначити, що на межі XX-XXI століть однією з основних рис саду останнього покоління виступають стіни, оформлені живими рослинами вертикальні насадження, відомі ще за часів Давньої Вавилонії [5]. Густі зарості плюща, бамбука, сотні кущів троянд, гліциній, аканта, лаванди, виноград, клени, липи, вишневі дерева переносять гостей парку до дивосвіту краси і гармонії.

Завдяки парку Promenad plante виникла ідея Хай-Лайну (Високої Лінії) - надземного парку в Нижньому Манхеттені (Нью-Йорк), розташованому на висоті 10 метрів від землі на місці надземної залізниці. Залізнична дорога Хай-Вей 3 естакадою - частина Нью-Йоркської Центральної залізниці - була збудована в 30-х pp. XX століття, щоб прибрати з вулиць товарні потяги, які перетворились на загрозу для пішоходів і заважали руху іншого транспорту. 3 роками навантаження перевезень падало, в 1980 рух лінією було перекрито, а естакада занедбана. Заснований наприкінці 90-х фонд «Друзі Хай-Лайн» розробив концепцію реконструкції залізничної лінії і перетворення іiі в парк. Представлена міській владі концепція знайшла підтримку у мера, пана Блумберга, і в 2005 р. фонд отримав 50 млн. доларів на втілення задуму. До новоствореного парку можна піднятися сходами або ліфтами. Більшість його доріжок викладені економними бетонними плитами, подекуди дерев'яним устилом, що нагадує палубу корабля. Парк урізноманітнюють лавки та столики зі стільцями, на яких можна відпочити та перекусити. Місць для сидіння багато, а хто надто втомився від прогулянки, може лягти і подрімати на спеціальних лавкахшезлонгах. Довкола підростають насаджені газони, і згодом на них теж зможуть полежати городяни. Старі залізничні рейки залишили як частину індустріального ландшафту, синтезованого із простором для відпочинку.

«Хай-Лайн», назва надземного парку в Нью-Йорку, вже перетворилася на прозивну. Як сповіщає преса, лондонська покинута дорога може стати новим «Хай-Лайном», свої «Хай-Лайни» планують відкрити і Бразиліа та 
Сеул. А, між тим, подібні проекти існували і в інших країнах, зокрема в Німеччині. Після Другої світової війни навкруг Берліну було чимало покинутих залізниць. За 50 років ділянка довкола однієї із старих розподільних підстанцій перетворилася на справжню оазу природи, місцями подібну до джунглів, завдяки створеному парку Шонебергер. Фахівці садового мистецтва не стали змінювати первинний вигляд підстанції, адміністративного будинку та водонапірної вежі, лише природний ландшафт пристосували для пішохідних прогулянок. У вересні 2011 р. почалося нове життя ще однієї ділянки, поцяткованої рейками i залишеної ще 1945. Це залізнична станція Райхсбан, у Східному Берліні, що не працювала вже більше 60 років. ÏÏ околиці належало перетворити на органічне продовження міського простору. Автори проекту обійшлися без зайвих прикрас: подіуми, сходи, лавки, доріжки - геть усе 3 дерев'яних рейок, таких відповідних залізничній тематиці середовища. Найбільш колоритними елементами інфраструктури стали збережені мости, цегляні стіни ангарів, бетонні забори. Ландшафтні архітектори відтворили формати, незамінні в межах міста: зелені галявинки, квітучі луки, декоративні гаї і чагарники, ліси з прогулянковими заасфальтованими доріжками, гравійні насипи з помостами і спортивні траси зі спеціальним погумованим покриттям. Тепер на 40 гектарах є де зайнятися спортом, відпочити чи погратися з дітьми.

\section{Парки на залізничних коліях корабелень}

Рейки - невід'ємний атрибут інфраструктури не тільки шляхів залізничних сполучень, але й корабелень та суднобудівних заводів. На полишеній корабельні у Чжуншані, в Китаї, архітектори та дизайнери в 2001 р. реалізували проект Парк Судноверф. Вдалий досвід когорти авторів презентує ландшафтну архітектуру як один із кращих інструментів перетворення міста. Доки та машини, що залишалися від корабельні, не можна було руйнувати з екологічних міркувань, тому вони були збережені у первісному вигляді або трансформовані. Доки пристосовувались під чайні чи клубні будинки, а водонагітна вежа перетворилась на маяк.

У Нормандії вся площа невеличкого півострова Роллє, яку займав суднобудівний завод, невдовзі після його зупинки перетворилася на пустир. В 2009 р. він потрапив під програму «Повернення природи у місто» і став ареною діяльності ландшафтного бюро. Впродовж 2 км примхливі форми берегової лінії ретельно відновили, а всією територією висадили 100.000 молодих рослин, завдяки яким у найближчі роки Роллє має перетворитися у «куточок незайманої природи».

\section{Паркова дорога (park way)}


Паркова дорога - схожа на парк місцевість, крізь яку пролягає дорога. Основний iї закон - безперервний і безупинний рух потоку машин забезпечує заборона перехрещених магістралей. Всі інші напрями йдуть через естакади чи шляхопроводи, а розв'язки утворюють форму «листка конюшини». До речі, зелений пояс, яким Осман у 60-ті роки XIX століття хотів оточити Париж, а також ті бульвари, що об'єднали систему парків у Чикаго на початку 90-х рр., теж входять до категорії паркових доріг. Міст через Темзу в Лондоні, повздовж якого планують висадити зелені рослини, також має увійти до цієї категорії. Паркова дорога не ідентична європейській автостраді, що, простягаючись прямою лінією подібно до залізниці, скорочує шлях між двома пунктами. Посередині паркової дороги зазвичай проходять озеленені полоси, які розділяють транспорт, що рухається у протилежному напрямі. Її полотно пристосовано до структури місцевості - підйомам, спадам, плавним заокругленням, а водії повинні кожного разу дотримуватись відповідної швидкості. Іноді окремі ділянки паркової дороги перетинають ріки - під мостами, підземними естакадами. Красу паркової дороги можна сприймати лише в русі. Навряд чи в іншому випадку, ніж під час проїзду такою дорогою, так сильно відчувається вплив сучасної концепції «простору-часу».

Ініціатива у створенні сучасної паркової дороги належить архітекторам Нью-Йорку. Дві такі дороги - паркова дорога Генрі Гудсона (1934-1937), та Норсерн-Стейт-Паркуєй (1931-1934) - огинають півострів Манхеттен і дозволяють перетнути його швидше, ніж на метро. Зразком органічного трасування паркової дороги може слугувати дорога Меррит у штаті Коннектикут, полотно якої пристосовано до особливостей ландшафту і структури грунту, розділено для пішохідного і транспортного руху.

Принцип паркової дороги можна розглядати як елемент майбутнього міста. Це перший крок до здійснення чіткого розділення пішохідного руху, транспорту та житлової забудови. Вона спрямована у майбутнє, коли будуть здійснені заходи по зміні структури міста. У парковій дорозі закладена тенденція забезпечити зв'язок житлової забудови і вуличного руху таким чином, щоб вони стали організуючими елементами міста [6].

\section{Література:}

1. Джон Ормсби Саймондо . Ландшафт и архитектура / пер. с англ. А.И. Маньшавина. Москва: Изд-во лит-ры по строительству, 1965. 194 с.

2. Turner Tom. Garden History: Philosophy and Design 2000 BC 2000 AD. London; New York: Spon Press, 2005. [IX]+ 294 p. 
3. Гамалія К.М. Синтетичний характер садово-паркового мистецтва. Вісник Львівської національної академії мистецтв. Вип. 24. 2013. C. $368-380$.

4. Кокуева И. Парижские парки. Ландшафтный дизайн. 2009. № 1. C. $96-99$.

5. Гамалія К.М. Зелена вертикаль у векторі часу. Науковий вісник НЛТУ України. Зб. науково-технічних праць. 2013. Вип. 23.9. С. 153-157.

6. Гидион 3. Пространство, время, архитектура / пер. с нем. М.В. Леонене, И.Л. Черня. 3-е изд. Москва: Стройиздат, 1984. 455 с.

DOI https://doi.org/10.30525/978-9934-26-004-9-83

\title{
КУЛЬТУРОЛОГІЧНИЙ ВИМІР МУЗИКОЗНАВСТВА ТА СВІТОВА ІНДУСТРІЯ ДОЗВІЛЛЯ
}

\author{
Діденко Н. О. \\ здобувач вищої освіти ступеня доктора філософії, \\ хореограф \\ ФОП «Діденко Н. О.» \\ м. Київ, Украӥна
}

3 моменту виокремлення Л. Уайтом культурології в самостійну науку [1] минуло не так багато часу, але й сьогодні вона перебуває, як і на стадії зародження, в статусі міждисциплінарної галузі знання та являе собою досить складну комбінацію різних наук. Серед інших (антропологія, етнологія, історія, філософія, соціологія, семіотика, психологія, філологія) одне з чільних місць посідає мистецтвознавство, адже культура і мистецтво хоча й не синонімічні поняття, але настільки близькі, що сприймаються соціумом тотожними. Подекуди ототожнюють мистецтвознавство і культурологію, вважаючи останню методом пізнання художньої творчості.

Насправді мова може йти тільки про культурологічний вимір мистецтвознавчих досліджень художньої реальності, оскільки предметом культурології в гносеологічному сенсі $€$ насамперед людина, аналіз системи іiі ідеалів та цінностей, приналежності до суспільного цілого та самоідентифікації в ньому як особистості. Відтак, культурологічний вимір будь-якої галузі знання чи мистецтва - це питання про 